\title{
Evaluation of the level of human impact on the river sediments in Russia
}

\author{
Valentina Kurochkina ${ }^{1 *}$ \\ ${ }^{1}$ Moscow State University of Civil Engineering, Yaroslavskoye Shosse, 26, Moscow, 129337, Russia
}

\begin{abstract}
The growing race of urbanization and population growth lead to anthropogenic load on the water is increasing all the time. High population density and considerable industrial potential of the urbanized territory are becoming dominant sources of pollution of water bodies. This trend identifies progressive pollution of water bodies and the growing need for sanitary-ecological status of water control facilities. Natural chemical composition and properties of water in surface water bodies are formed depending on the hydrological, soil, climate and other features. Flowinduced suspensions in urban watercourses is one of the main ways of contamination distribution in urbanized areas. For monitoring and reducing the negative impacts on the water quality of watercourses requires estimation of anthropogenic pressures and studying its spatio-temporal variability. Analysis of anthropogenic stress on water objects allows you to set the relationship between the number of coming in the water body of pollutants and concentrations of chemicals in the water. The main aim is to determine the amounts of contaminants accumulated in the river riverbed during the period of the economic utilization of the watercourse and to assess the impact of urbanization on its ecological status. The article deals with the influence of anthropogenous load on river hydraulics and properties of channel sediments that determine the course of channel processes and overall ecological condition of water objects. The interrelation between water body condition, water quality and sediment pollution is presented. Method of estimation of anthropogenous load pollutants in river of urban area sis proposed. Comparative analysis of the load for the rivers of Russia with various water run-off is demonstrated.
\end{abstract}

\section{Introduction}

The growing race of urbanization and population growth lead to anthropogenic load on the water is increasing all the time. In Russia the urbanization processes proceed more intensely than in other countries. During the period 1950-1990 percentage of urban population increased from $29 \%$ to $42 \%$ in our planet, and in Russia, with $48 \%$ to $75 \%$ [1]. High population density and considerable industrial potential of the urbanized territory are becoming dominant sources of pollution of water bodies [2,3]. This trend identifies progressive pollution of water bodies and the growing need for sanitary-ecological status of water control facilities [4].

\footnotetext{
*Corresponding author: kurochkina@mgsu.ru
} 
The effects of technogenesis have an increasing effect on river hydraulics and the properties of riverbed deposits, which determine the course of riverbed processes and the general ecological state of water bodies. The main factors affecting the state of a water body include:

- quantitative and qualitative characteristics of pollution sources in urban areas affecting water quality;

- hydraulic and hydrogeological characteristics of the water body, which determine the conditions for the deposition of particles and the formation of contaminated bottom sediments;

- composition and properties of contaminated bottom sediments;

- $\quad$ secondary pollution, a significant manifestation of which can have a great negative impact on water quality and self-putification processes of the hydroecosystem.

The ecological state of water bodies is often associated with the self-purification ability of a water body, which implies that part of the pollutants in the water either goes into a „neutral“" state or is „released“ from the water stream. The latter condition is achieved due to sedimentation processes, during which contaminants from the water mass are adsorbed and, precipitating, form bottom sediments. Conditions of particle sedimintation in river beds are complex processes that depend on hydrodynamic, hydrological, morphological and other flow conditions and will not be considered in this paper.

Contaminants, forming complex compounds, can exhibit migration properties to a greater or lesser extent depending on various factors, the level of organic substances or the $\mathrm{pH}$ of the medium, which can significantly vary during the year. Therefore, for a general assessment of the ecological state of a water body, it is not enough to take into account the level of water pollution in the water body, the ability of this water body to self-purification, but it is also necessary to have a reasonable idea of the volume, thickness and level of pollution of bottom sediments [1].

For monitoring and reducing the negative impacts on the water quality of watercourses requires estimation of anthropogenic pressures and studying its spatio-temporal variability. Analysis of anthropogenic stress on water objects allows you to set the relationship between the number of coming in the water body of pollutants and concentrations of chemicals in the water [5]. The main aim is to determine the amounts of contaminants accumulated in the river riverbed during the period of the economic utilization of the watercourse and to assess the impact of urbanization on its ecological status $[6,7,8]$.

Natural chemical composition and properties of water in surface water bodies are formed depending on the hydrological, soil, climate and other features. The natural character of the changes in the composition of the water is associated with seasonal fluctuations of hydrometeorological conditions and intensity of biological processes [9].

Currently, water sources pollution are both natural and man-made disasters, which are related to human activities.

Flow-induced suspensions in urban watercourses is one of the main ways of contamination distribution in urbanized areas. Take away mists with the urbanized territories can be repeatedly exceed the amount entering the watercourse of the natural landscapes of the same area [10].

Water objects are exposed to discharges of waste water containing oil and other organic substances ambarrased water aerating. More dangerous are heavy metal compounds, which are distinguished by high toxicity for organisms at relatively low concentrations in waters. On the other side they have the ability to bioaccumulate and biomagnify in organisms [11].

Strengthening the control of wastewater resulted at the present stage of all important role in the formation of solid runoff from urban areas play a so-called "area sources" from the surface flushing pollutants. So, according to official data from the territory of Moscow located within the hydrographic network annually from surface runoff flows about 500 
thousand tons suspended solids and volume of solid flow in wastewater dumped household objects is 20.5 thousand tons. [12, 13 Janin, 2009, Anonym, 1993].

Surface water discharges from construction sites, housing estates and roads resulting from rainfall, snowmelt and watering-washing machines manufacturing works, are characterized by heterogeneity of composition highly polluted with oil products and are usually not cleaned along with the sewage [14].

They deliver in watercourse chemical impurities in the form of weighted, emulsified and dissolved substances inorganic and organic nature of different size and different physical and mechanical properties associated with their artificial origin [15]. Part of the dirt falls out of the air as polluted atmosphere contains particles of dust, soot, aerosols, gases which are the initiators of "acid rain"- oxides and sulphur dioxides, nitrogen, carbon. They fall into the atmosphere with emissions of engines of internal combustion cars, emissions from industrial smokestacks and power plants.

Long-term management of watercourses in cities as receivers of waste and wastewater, resulted in the accumulation of sediments in the chemicals and compounds hazardous to ecosystems and human health. Because of high sorption properties and mobility processes of equilibrium between the liquid and solid phases, sediments can be considered as one factor of self-purification and source of secondary contamination of ecosystems watercourse [16].

Ingress of chemical additives and artificial compounds in bottom sediments also leads to a change in their physical - mechanical properties, improves connectivity, which in turn hinders the natural processes of self-purification of water objects. The impact of urbanization on watercourse depend on the ratio between the watercourse and "power" (area, population, development of industry) center of urbanization [17, 18].

\section{Methods}

As dimensionless quantify the total scale or degree of impact on the watercourse may be used anthropogenic pressure of sewage water $\mathrm{M}_{\mathrm{vl}}$, defined as the ratio of total waste and effluent flow rate $\left(Q_{c}\right)$ to the annual average consumption of the watercourse $(\mathrm{Q})$ :

$$
\mathrm{M}_{\mathrm{vl}}=\mathrm{Q}_{\mathrm{c}} / \mathrm{Q}^{*} 100 \%
$$

where $\mathrm{M}_{\mathrm{vl}}$ - coefficient of anthropogenous load from sewage, \%;

$\mathrm{Q}_{\mathrm{c}}$ - the annual amount of waste water, $\mathrm{km}^{3} /$ year;

$\mathrm{Q}$ - water flow of the river, $\mathrm{km}^{2} /$ year.

When $\mathrm{M}_{\mathrm{vl}}<1$ controlled impacts of urbanization on watercourse allows in some cases at the expense of significant flood costs $\left(\mathrm{Q}_{\mathrm{n}}>>\sum \mathrm{Q}_{\mathrm{c}}\right)$ the river's self-purification capacity and save it to support a balanced ecological system, close to the natural. When $\mathrm{M}_{\mathrm{vl}}>1$ maintain satisfactory sanitary condition of the watercourse and maintain ecological system becomes more complex and costly as inequality. In some cases, due to the irreversible changes river bed and complete degeneration of the ecological systém, to return to an acceptable watercourse State is impossible without implementation of large complex of water protection measures and cleanup of contaminated site.

The influence of urbanization centers generally does not extend to the entire watercourse as a whole (unless it refers to small rivers), and water quality and pollution character of river channels is determined by the characteristic composition and quantity of contaminants entering the water facilities with those centres. Therefore, solving environmental issues and environmental safety, it is convenient to view security anthropogenic load on the river, not only as a load from a variety of sources of pollution, but also how to load individual river pollutants. In this case, the load will be characterized 
by the coefficient of anthropogenic pollutant load $(\mathrm{Ki})$, defined as the ratio of the mass $\left(\mathrm{m}_{\mathrm{i}}\right)$ pollutant in wastewater volume in the annual river drain at urbanization:

where $\mathrm{K}_{\mathrm{i}}$ - pollutant load, $\mathrm{t} / \mathrm{km}^{3}$;

$\mathrm{m}_{\mathrm{i}}$ - the annual flow of the pollutant in the watercourse, $\mathrm{t} / \mathrm{year}$;

$\mathrm{Q}$ - water flow of the river, $\mathrm{km}^{3} /$ year;

$\mathrm{C}_{\mathrm{i}}$ - the concentration of the pollutant, $\mathrm{t} / \mathrm{km}^{3}$.

The most universal characteristic of anthropogenic load can serve as a normalized load individual pollutants (c'i) calculated for MACS these substances (MPCi):

$$
K_{i}^{\prime}=\frac{C_{i} \cdot Q_{c}}{Q \cdot M P C_{i}}
$$

From the equation we can be seen that when $\mathrm{K}^{\prime}<1$, watercourse, on average, able to dilute the incoming contaminant below PDK, when $\mathrm{K}^{\prime}>1$ in water object will experience increased anthropogenic stresses the polluting substance that could adversely affect the ecological condition of the watercourse.

\section{Results and discussion}

The volume of sewage into rivers of Russia is distributed very unevenly. Annual flow of river Volga is only $6 \%$ of all river flow, whereas in the basin of the river Volga dumped the greatest amount of wastewater is 18049.3 million m3/year (Table 1), representing $30.2 \%$ from volume of wastewater, emerging across the country [1].

Table 1. Antropogenic load of pollutants in the major Russian rivers.

\begin{tabular}{|c|c|c|c|c|c|c|c|}
\hline \multirow{2}{*}{ River name } & Volga & $\mathrm{Ob}$ & Enisey & Lena & Кама & $\begin{array}{l}\text { North } \\
\text { Dvina }\end{array}$ & Neva \\
\hline & \multicolumn{4}{|c|}{$\begin{array}{l}\text { Major rivers with an annual flow more } \\
\text { than } 200 \mathrm{~km}^{3} / \text { year }\end{array}$} & \multicolumn{3}{|c|}{$\begin{array}{l}\text { Major rivers with an annual } \\
\text { flow more than } 75 \mathrm{Km}^{3} / \text { year }\end{array}$} \\
\hline $\mathrm{S}$, thousand $\mathrm{m}^{2}$ & 1360.0 & 2990.0 & 2580.0 & 2490.0 & 507.0 & 375,0 & 281,0 \\
\hline $\mathrm{Q}_{\mathrm{c}}, \mathrm{t}^{3} /$ year & 18.049 & 6.723 & 3.146 & 0.117 & 4.208 & 109,0 & 78,5 \\
\hline $\mathrm{Q}, \mathrm{t}^{3} /$ year & 254.0 & 404.0 & 630.0 & 532.0 & 117.0 & 0,926 & 0,679 \\
\hline $\mathrm{M}_{\mathrm{vl}}, \%$ & 7 & 2 & 1 & 0.0 & 4 & 0,8 & 0,9 \\
\hline $\mathrm{m}_{\mathrm{Fe}}, \mathrm{t} /$ year & 22210 & 1257 & 516 & 18 & 19206 & 25 & 641 \\
\hline $\mathrm{m}_{\mathrm{Cu}}, \mathrm{t} / \mathrm{year}$ & 498 & 35 & 6 & 0.06 & 32 & 0,3 & 14 \\
\hline $\mathrm{m}_{\mathrm{Zn}}, \mathrm{t} / \mathrm{year}$ & 463 & 96 & 31 & 1.6 & 139 & 4,4 & 56 \\
\hline $\mathrm{K}_{\mathrm{Fe}}, \mathrm{t} / \mathrm{km}^{3}$ & 87.44 & 3.11 & 0.82 & 0.03 & 164.15 & 0.23 & 8.17 \\
\hline $\mathrm{K}_{\mathrm{Cu}}, \mathrm{t} / \mathrm{km}^{3}$ & 1.96 & 0.09 & 0.01 & 0.00 & 0.27 & 0.0028 & 0.1783 \\
\hline $\mathrm{K}_{\mathrm{Zn}}, \mathrm{t} / \mathrm{km}^{3}$ & 1.82 & 0.24 & 0.05 & 0.00 & 1.19 & 0.04 & 0.71 \\
\hline $\mathrm{K}_{\mathrm{Fe}}^{\prime}$ & 0.8744 & 0.0311 & 0.0082 & 0.0003 & 1.6415 & 0.0023 & 0.0817 \\
\hline $\mathrm{K}_{\mathrm{Cu}}^{\prime}$ & 1.9606 & 0.0866 & 0.0095 & 0.0001 & 0.2735 & 0.0028 & 0.1783 \\
\hline $\mathrm{K}_{\mathrm{Zn}}^{\prime}$ & 1.823 & 0.238 & 0.049 & 0.003 & 1.188 & 0.0040 & 0.0713 \\
\hline
\end{tabular}

When this drainage area $(\mathrm{S})$ of the Volga River is lesser to other major rivers, annual runoff which exceeds $200 \mathrm{~km}^{3} /$ year. For example, pool and pool the Yenisei and $\mathrm{Ob}$ exceed its square in 2.2 and 2 times respectively, and water drain these rivers in 1.6 and 2.5 times exceed the Volga runoff (Table 1).

Among the major rivers of Russia Volga is the most polluted. The amount of pollutants entering the river is 22210 tons/year of iron, 498 tons per year of copper and $463 \mathrm{t}$ per year of zinc.

Table 1 shows the values of the quantity of pollutants for iron river basin $(\mathrm{mFe})$ and copper $(\mathrm{mCu})$ (heavy metals of the third class of danger), and zinc (mZn) [19] relating to the fourth class of danger. Calculation of load of individual pollutants has shown that the 
greatest threat is contamination of copper $\left(\mathrm{K}^{\prime}{ }_{\mathrm{Cu}}=1.96\right)$ and zinc $\left(\mathrm{K}^{\prime}{ }_{\mathrm{Zn}}=1.82\right)$ for the Volga River, which are prevalent contaminants.

Among the major rivers with an annual flow of more than $75 \mathrm{~km}^{3} /$ year, the greatest load is on the river Kama. Calculation of load of individual pollutants has shown that the greatest threat is posed by the pollution of iron $\left(\mathrm{K}_{\mathrm{Fe}}^{\prime}=1.64\right)$ and zinc $\left(\mathrm{K}^{\prime} \mathrm{Zn}=1.19\right)$ for the Kama river, for which the value of the load exceeds one.

On the basis of calculations you can determine the dominant contaminants, on the basis of which can be installed level anthropogenous load on that or other watercourse. As total dimensionless quantify anthropogenic load a watercourse can be used integrated quantifies the anthropogenic burden (ton), expressed as follows [20]:

$$
K=\sum_{i=1}^{n} \frac{C_{i} \cdot Q_{c}}{Q \cdot M P C_{i}}
$$

where $\mathrm{i}=1,2 \ldots \mathrm{n}$-defined pollutants.

Out of the equation it can be seen that when $K_{n}<1$, watercourse on average is able to dilute the incoming impurities below the PDK, when $K_{n}>1$ the ecological status of a watercourse is disturbed.

We would note that when calculating totals, or while the contents of the substances in the water should take into account emission it is necessary to calculate the limiting rate of harmfulness and consequently calculating the total rated load $\mathrm{K}_{\mathrm{n}}$ will participate concentration (with $1,2, \ldots, \mathrm{n}$ ) substances with the same limiting sign.

This expression for $\mathrm{K}_{\mathrm{H}}$ is approximate since it does not take into account the background of water pollution $\mathrm{C}_{\mathrm{Fi}}$ to centrum of urbanization (calculation of $\mathrm{C}_{\mathrm{fi}}$ ) acquires more precise meaning of factor describing the column total amount of anthropogenous load on river $\mathrm{K}_{\mathrm{E}}$ :

$$
K_{E}=\sum_{i=1}^{n} \frac{C_{i} \cdot Q_{c}}{Q \cdot\left(M P C_{i}-C_{F i}\right)}
$$

As mentioned above, the river water pollution as a result of contact with bottom sediments leads to the accumulation of a large number of pollutants. Accumulating heavy metals, mineral and organic substances, sediment contributing to self-cleaning water environment. However, accumulated in the sediment contaminants under certain conditions can navigate in soluble forms and pollute the water, even if there is no external load (secondary pollution). According to the performed calculations, length of contaminated sites in the riverbed on the small and medium-sized rivers can reach hundreds of meters and in some cases tens of kilometres (Kurochkina, 2012). Analysis of studies shows that watercourses under the considerable anthropogenic load, the average annual rate of rise of contaminated sediment thickness varies from 0.5 to $5.0 \mathrm{~cm} /$ year. In this case, per 50 year period, economic use and contamination of watercourses, the thickness of a layer of contaminated bottom sediments reaches $0.25 \pm 2.5 \mathrm{~m}[20]$.

\section{Summary}

To improve the ecological state of watercourses should improve the monitoring and control of the quality and volume of sewage water users registered, as well as to continue its record of pollution sources. To assess anthropogenic load on the proposed methodology for the necessary reliable data about the waterflow of the river can be obtained in the literature, data on the quantities of waste water and the quantity of pollutants for each water user get quite difficult. Various data sources can vary considerably.

In conclusion, I would like to note that the obtained results confirm the high degree of average annual toxic load on the Volga ecosystems. 
The proposed methodology can be used in the development of environmental programs aimed at reducing the anthropogenic pressure on rivers, since the improvement of the ecological state of a water body can be achieved only within the framework of a single program, which includes a set of measures to improve the quality of discharged wastewater, regulation of the hydraulic and hydrogeological characteristics of the water body, measures to remove contaminated bottom sediments, etc.

However, in order to increase the accuracy in determining the level of anthropogenic load, it is necessary to improve monitoring and control over the volume and quality of wastewater of registered water users, and also continue to take into account pollution sources. This is due to the fact that if necessary reliable data on the river's water flow can be obtained in the specific literature in order to estimate the anthropogenic load (according to the proposed methodology), then data on the volume of wastewater and the amount of pollutants for each water user is rather difficult to obtain.

\section{References}

1. A.T. Nikitin, S.A. Stepanov, V.P. Chizhova et al., Ecology, nature protection and environmental safety. The manual for training and retraining of public servants. Publ. House MNEPU, Moscow (1997)

2. A.V. Selezneva, News of the Samara scientific centre of Russian Academy of Sciences, 5(2), 268-277 (2003)

3. H. Züllig, Sedimente als Ausdruck des Zustandes eines Gewässers. Schweiz. Z. Hydrol. 7-143 (1956)

4. T.G. Bogomolova, V.A. Kurochkina, Engineering researches, 56-60 (2010)

5. U. Förstner, G. Müller, , Schwermetalanreichungen in datierten Sediment-kernen aus dem Bodensee und aus dem Tegernsee: Tschrmaks Min. Petr. Mitt. 21, 145-163 (1974)

6. T.I. Eroshina, L.N. Shikhova, E.M. Lisitsyn, A.S. Zhiryakov, Problems of regional ekology 2, 17-23 (2007)

7. A.M. Josefowicz,.N.E. Kosheleva. Theoretical and applied ecology 3, 35-42 (2009).

8. E.P. Janin, Theoretical and applied ecology 9(1), 66-71 (2009)

9. G. Müller, UmweltgeologieBand. Wien, 107-126 (2003)

10. V.V. Kupriyanov, Hydrological aspects of urbanization. Leningrad, Gidrometeoizdat, (1977)

11. U. Förstner, G. Müller, Schwermetalanreichungen in datierten Sediment-kernen aus dem Bodensee und aus dem Tegernsee: Tschrmaks Min. Petr. Mitt. 21, 145-163 (1974)

12. E.P. Janin. Scientific and technical aspects of environmental protection 6, 2-56 (2002)

13. Governmental report on the State of the environment of Moscow in 1992. Moscow: ITF ESSO (1992)

14. H. Heinrichs, Unpubl. habil. thesis, Univ. Göttingen, (1993)

15. J.B. Ellis, Man's impact on the hydrological cycle in the UK, 199-216. Geobooks, Norwich, UK (1979).

16. V.I. Kosov, G.N. Ivanov, V.V. Levinskii, E.V. Vodn. Resur., 28(5) 448-453 (2001)

17. G. Müller, Mitt. österr. Geol. Ges., 107-126 (1986).

18. J. Dominik, A. Mangini, F. Prosi, Environmental Geology 5(3), 151-157 (1983)

19. A.M. Chernyaev, M.A. Gering, L.P. Belova, N. B. Prokhorova, Water of Russia (condition, use, conservation). Statement in 1995. Ekaterinburg: Rosniivh (1996)

20. V.A. Kurochkina,. Formation and environmental properties of Channel sediment in streams in the urbanized territories. DIS. On the Cand. of technical sciences. Moscow State building University (2012) 